\title{
PENERAPAN MEDIA AUDIO VISUAL DALAM PENINGKATAN ANGKA PEMBERIAN AIR SUSU IBU (ASI) EKSKLUSIF DI DESA KUROTIDUR KECAMATAN ARGAMAKMUR KABUPATEN BENGKULU UTARA
}

\author{
Wulan Angraini $^{1)^{*}}$, Cahyo Prihantoro ${ }^{2)}$, M. Amin ${ }^{1)}$, Bintang Agustina $\mathbf{P}^{1)}$, \& Riska \\ Yanuarti $^{1)}$ \\ ${ }^{1)}$ Program Studi Kesehatan Masyarakat, Universitas Muhammadiyah Bengkulu \\ ${ }^{2)}$ Program Studi Teknik Informatika, Fakultas Teknik, Universitas Muhammadiyah \\ Bengkulu \\ wulanangraini@umb.ac.id
}

\begin{abstract}
ABSTRAK
Air Susu Ibu adalah sumber gizi sehat untuk bayi. Pemberian ASI Eksklusif didefinisikan WHO yaitu menyusui bayi dengan hanya ASI selama 6 bulan pertama dalam kehidupan bayi tanpa memberikan makanan dan minuman tambahan kecuali obat dan vitamin dan terus memberikan ASI tersebut hingga 2 tahun. Pemberian ASI eksklusif sangat penting karena merupakan makanan utama dan pertama yang mengandung zat-zat lengkap yang dibutuhkan bayi untuk pertumbuhan, perkembangan bayi serta memberikan manfaat kekebalan tubuhnya. ASI tidak tertandingi oleh makanan apapun. Pemberian ASI eksklusif pada bayi akan meningkatkan involusi rahim sehingga mengurangi komplikasi masa nifas. Memberikan ASI juga berdampak positif bagi ibu karena isapan bayi akan menyebabkan kontraksi uterus yang mencegah perdarahan post-partum.Pada saat menyusui juga melepaskan oksitosin setelah melahirkan, juga mengurangi perdarahan rahim serta mencegah sekitar seperlima dari kematian neonatal. Konseling gizi dan laktasi pada saat kehamilan dan setelah melahirkan melalui kunjungan rumah berpengaruh terhadap peningkatan pengetahuan,sikap ibu tentang ASI Eksklusif.
\end{abstract}

\section{Kata Kunci : ASI Eksklusif, Ibu Hamil, Konseling}




\section{PENDAHULUAN}

ASI adalah sumber gizi sehat untuk bayi. Pemberian ASI Eksklusif didefinisikan WHO yaitu menyusui bayi dengan hanya ASI selama 6 bulan pertama dalam kehidupan bayi tanpa memberikan makanan dan minuman tambahan kecuali obat dan vitamin dan terus memberikan ASI tersebut hingga 2 tahun (WHO, 2009). Pada bulan Mei 2012, negara-negara anggota WHO memberikan strategi global dorongan lebih lanjut untuk mendukung rencana implementasi yang komprehensif bagi ibu, bayi dan gizi anak muda. Salah satu dari enam target rencana adalah setidaknya $50 \%$ dari bayi berusia di bawah 6 bulan diberikan ASI Eksklusif pada tahun 2025. Hanya sekitar 38\% dari bayi usia 0 sampai 6 bulan di seluruh dunia yang diberikan ASI Eksklusif. Di Rusia dan negara-negara Eropa hanya $40 \%$ atau kurang dari bayi di bawah enam bulan yang diberikan ASI Eksklusif (WHO, 2014).

Di Indonesia presentasi bayi yang Inisiasi Menyusui Dini kurang dari satu jam setelah bayi lahir adalah 34,5\% dan presentasi bayi diberi ASI Eksklusif tercatat pada bayi $0-6$ bulan pada usia 0 bulan $52,7 \%$, usia 1 bulan $48,7 \%$, usia 2 bulan $46,0 \%$, usia 3 bulan $42,2 \%$, usia 4 bulan $41,9 \%$, usia 5 bulan $36,6 \%$ dan usia 6 bulan 30,2\% (Riskesdas, 2013).

Hasil Pemantauan Status Gizi (PSG) tahun 2017, persentase bayi baru lahir yang mendapat IMD dalam $<1$ jam setelah lahir pada tahun 2017 sebesar 51,3. Persentase tertinggi $(62,3 \%)$ di Provinsi Sumsel dan terendah $(25,6 \%)$ Bengkulu, (25,0\%) Papua .(Kemenkes, 2017).

Lebih dari 30 penelitian dari seluruh dunia baik negara berkembang dan negara maju telah menunjukkan hasil yaitu bahwa menyusui mengurangi risiko atau mencegah lebih dari tiga perempat dari kematian pada awal kehidupan masa bayi dan 37\% kematian selama tahun kedua kehidupan. Apabila setiap bayi yang baru lahir disusui dalam waktu satu jam setelah melahirkan, hanya diberikan ASI selama enam bulan pertama kehidupan, terus menerus menyusui sampai dua tahun, sekitar 800.000 jiwa anak akan terselamatkan setiap tahun (WHO, 2014).

Seiring hasil kajian WHO tersebut, Departemen Kesehatan telah memberikan kebijakan melalui Keputusan Menteri Kesehatan No:450/Menkes/SK/IV/2004 yang menetapkan bahwa pemberian ASI secara Eksklusif bagi bayi di Indonesia adalah sejak lahir sampai dengan bayi berumur 6 bulan dan semua tenaga kesehatan agar menginformasikan kepada semua ibu yang baru melahirkan untuk memberikan ASI secara eksklusif. Selain itu, kebijakan pemberian ASI eksklusif juga terdapat dalam Undang - Undang Nomor 36 tahun 2009 Pasal 128 ayat (1) bahwa setiap bayi berhak mendapatkan Air Susu Ibu (ASI) Eksklusif sejak dilahirkan selama 6 bulan kecuali atas indikasi medis (Kemenkes, 2010). Pada tahun 2006 pemerintah Indonesia mentargetkan minimal $80 \%$ bayi di Indonesia disusui secara eksklusif. Namun kebijakan ini berubah pada tahun 2013 dimana pemerintah mengubah target minimal bayi yang disusui menjadi 75\% (Kemenkes, 2013).

Pemberian ASI eksklusif sangat penting karena merupakan makanan utama dan pertama yang mengandung zat-zat lengkap yang dibutuhkan bayi untuk pertumbuhan, perkembangan bayi serta memberikan manfaat kekebalan tubuhnya. ASI tidak tertandingi oleh makanan apapun. Pemberian ASI eksklusif pada bayi akan meningkatkan involusi rahim sehingga mengurangi komplikasi masa nifas. Memberikan ASI juga berdampak positif bagi ibu 
karena isapan bayi akan menyebabkan kontraksi uterus yang mencegah perdarahan post-partum. Hal ini bisa menurunkan angka kesakitan dan kematian ibu pasca melahirkan. Menyusui mengurangi kanker ovarium $27 \%$ sampai $40 \%$ dan kanker payudara sebesar $40 \%$ sampai $80 \%$. Pada saat menyusui juga melepaskan oksitosin setelah melahirkan, juga mengurangi perdarahan rahim serta mencegah sekitar seperlima dari kematian neonatal (WHO, 2014)

Faktor yang berhubungan dengan pemberian ASI eksklusif adalah pekerjaan ibu, dukungan tenaga kesehatan, dukungan orang tua, dukungan suami, penyuluhan tentang ASI eksklusif dan sikap ibu. Faktor yang paling dominan yang mempengaruhi yaitu dukungan orang tua, status pekerjaan ibu, penyuluhan tentang ASI eksklusif (Ayu, 2016). Upaya faktor pendorong ibu memberikan ASI Eksklusif adalah pengetahuan yang baik tentang ASI sangat mendukung keberhasilan pemberian ASI eksklusif. Motivasi diri sendiri dan dukungan keluarga dapat mendorong keberhasilan pemberian ASI eksklusif. Perilaku IMD pada ibu juga dapat mendukung keberhasilan pemberian ASI eksklusif (Martini dan Astuti, 2017).

Penelitian Nuraeni dkk (2014), intervensi konseling dan pendampingan suami mempunyai peluang 7 kali lebih besar untuk memberikan kolostrum pada bayinya dibandingkan dengan kelompok kontrol responden yang tidak diberikan konseling dan pendampingan suami sedangkan penelitian dari Ramlan dkk (2015), menyatakan bahwa konseling gizi dan laktasi pada saat kehamilan dan setelah melahirkan melalui kunjungan rumah berpengaruh terhadap peningkatan pengetahuan,sikap ibu tentang ASI Eksklusif.
Khotimah, Kamasi dan Yuhbaba (2014) menyatakan ibu yang mendapatkan konseling sebagian besar memberikan ASI secara Eksklusif pada bayi selama 24 jam yaitu $74.04 \%$. Hasil penelitian ini menunjukkan bahwa ibu yang mendapatkan konseling memiliki kecenderungan memberikan ASI Eksklusif pada bayi. Keadaan ini mengindikasikan bahwa perilaku ibu cenderung didasari oleh informasi yang diketahuinya. Ibu yang tidak diberikan konseling memberikan ASI secara Eksklusif pada bayi selama 24 jam yaitu $33.33 \%$. Hasil penelitian ini menjelaskan bahwa ibu yang tidak mendapatkan konseling memiliki memiliki kemungkinan memberikan ASI Eksklusif pada bayi. Hal ini diduga ibu mengetahui manfaat ASI Eksklusif dari sumber lainnya.

Vidayanti \& Melania (2017), konseling laktasi berpengaruh terhadap kemampuan menyusui ibu pasca bedah sesar, ibu yang mendapatkan konseling laktasi berpeluang mempunyai kemampuan menyusui yang lebih baik terhadap bayinya bila dibandingkan dengan ibu yang tidak mendapatkan konseling laktasi.

Menurut data profil kesehatan Indonesia pada tahun 2016 cakupan ASI Eksklusif di Bengkulu menunjukkan hanya sekitar $42,5 \%$ dan pencapaian ASI Eksklusif tahun 2015 sebesar $76,1 \%$, pada tahun 2014 sebesar 78,5\% yang mendapatkan ASI Eksklusif. Dari data profil kesehatan Indonesia ini didapatkan terjadinya penurunan dibandingkan dengan tahun sebelumnya.

Berdasarkan penjelasan diatas, kami selaku Dosen Pembimbing Lapangan dan Mahasiswa KKN yang terdapat di wilayah desa Kuro Tidur Kecamatan Argamakmur Kabupaten Bengkulu Utara mencoba menawarkan pendidikan dan pemeriksaan kesehatan kepada para ibu hamil untuk peningkatan pengetahuan dan 
pengontrolan kesehatan ibu hamil menjelang hari pertama lahir sang bayi sehingga pada saat melahirkan ibu telah siap untuk memberikan Air Susu Ibu (ASI) secara benar serta memotivasi ibu tentang kemanfaatan Inisiasi Menyusu Dini (IMD) guna melahirkan generasi yang berkualitas dengan demikian terwujudnya peningkatan angka pemberian ASI Eksklusif di Desa Kuro Tidur Kecamatan Argamakmur Kabuapten Bengkulu Utara.

\section{METODE KEGIATAN}

Pelaksanaan pengabdian kepada masyarakat ini dilakukan di desa Kuro Tidur Kecamatan Argamakmur Kabupaten Bengkulu Utara. Pelaksanaan kegiatan pengabdian kepada masyarakat 24 Juli -08 September 2018

\section{A. BENTUK KEGIATAN}

\section{Pendidikan Kesehatan}

Untuk meningkatkan pengetahuan dan pemahaman tentang Insiiasi Menyusu Dini dan Air Susu Ibu secara Eksklusif. Pendidikan kesehatan dilakukan dengan cara penyuluhan yang akan dilakukan dalam bentuk metode ceramah dan menggunakan media audio visual dengan tujuan para ibu hamil lebih tertarik dan mudah dipahami manfaat dari Inisiasi Menyusu Dini dan ASI Eksklusif.

\section{Pemeriksaan Kesehatan}

Untuk mengetahui dan mengontrol tekanan darah, kadar kolestrol, kadar gula darah dan asam urat ibu hamil.

\section{Pendampingan}

Dari hasil tahapan di atas, petugas kesehatan akan melakukan pendampingan pada ibu hamil untuk memberikan IMD dan ASI secara Eksklusif.

\section{HASIL DAN PEMBAHASAN}

\section{a. Kegiatan Survei Lapangan}

\section{A. Pembukaan}

Pelaksanaan survei lapangan dilaksanakan pada pukul 09.00 WIB s/d Selesai oleh dosen pendamping lapangan dan mahasiswa kuliah kerja nyata (KKN) di Balai Desa Kuro Tidur Kecamatan Argamakmur Kabupaten Bengkulu Utara

B. Pelaksanaan

Pelaksanaan survei lapangan pada tanggal 24 Juli 2018 diikuti oleh 20 oang yang terdiri dari kepala desa dan perangkat desa, karang taruna, dosen pendamping lapangan dan mahasiswa kuliah kerja nyata (KKN), Pihak Puskesmas Perumnas Kabupaten Bengkulu Utara

C. Evaluasi

Tercapainya tujuan pengabdian kepada masyrakat dalam bentuk pemeriksaan kesehatan akan dilaksanakan pada tanggal 10 Agustus 2018 bertempat di Dusun I Desa Kuro Tidur Kecamatan Argamakmur Kabupaten Bengkulu Utara dan pelaksanaan Pendidikan kesehatan dalam bentuk penyuluhan kesehatan pada tanggal 5 September 2018 yang bertempat di Dusun Empat Desa Kuro Tidur Kecamatan Argamakmur Kabupaten Bengkulu Utara dengan baik, lancar dan sukses serta agar masyarakat sekitar desa dapat menerima kehadiran mahasiswa kuliah kerja nyata (KKN) 


\section{b. Kegiatan Pemeriksaan Kesehatan}

A. Pembukaan

Acara dimulai dengan pembukaan dari mahasiswa Kuliah Kerja Nyata $(\mathrm{KKN})$ dari Dosen Pembimbing Lapangan Universitas Muhammadiyah Bengkulu oleh Wulan Angraini, SKM., MKM dilanjutkan dengan kegiatan Pemeriksaan Kesehatan di Balai Dusun I Desa Kuro Tidur Kecamatan Argaakmur Kabupaten Bengkulu Utara bekerja sama antara piak Puskesmas Perumnas dan Mahasiswa Kuliah Kerja Nyata Universitas Muhammadiyah Bengkulu.

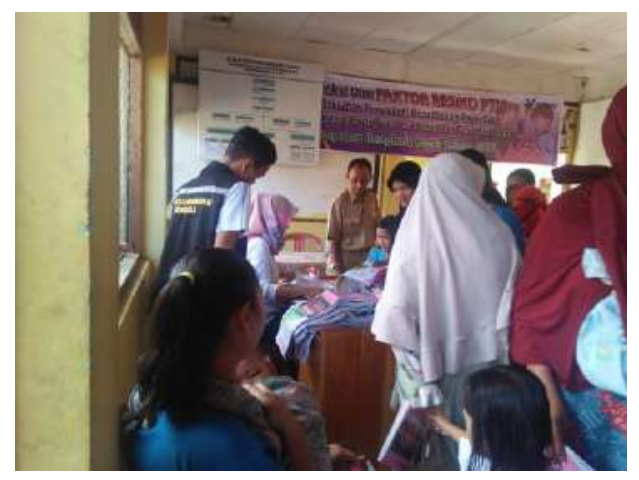

B. Pelaksanaan

Pelaksanaan pemeriksaan kesehatan dilakukan oleh pihak Puskesmas Argamakmur dan mahasiswa Kuliah Kerja nyata (KKN) UNiversitas Muhammadiyah Bengkulu pada tangga 10 Agustus 2018 bertempat di Balai Dusun I Desa Kuro Tidur Kecamatan Argamakmur Kabupaten Bengkulu Utara

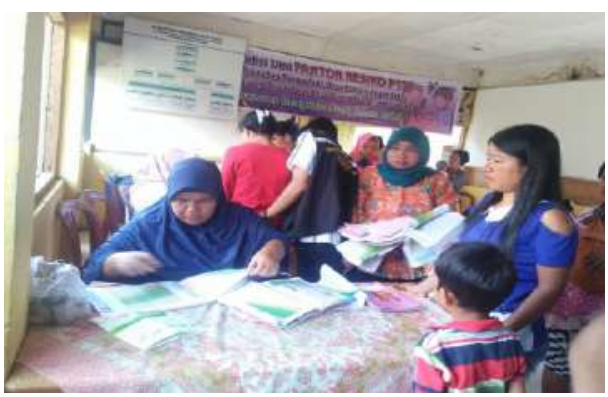

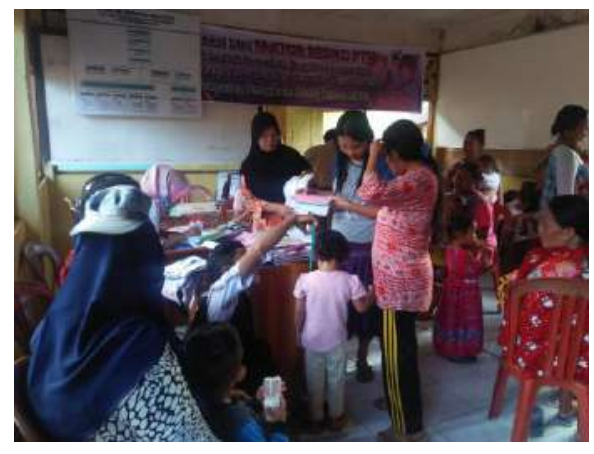

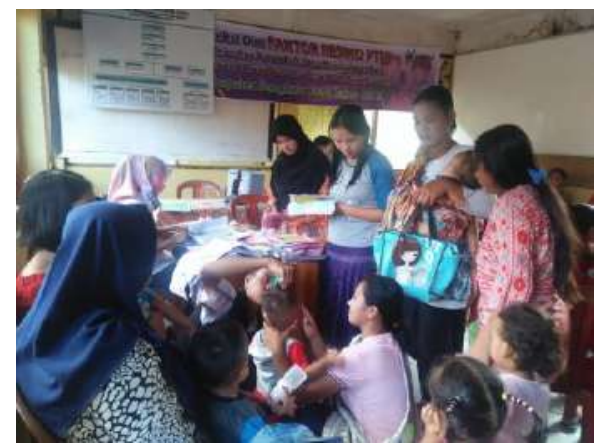

C. Evaluasi

Dari hasil pemeriksaan kesehatan di Balai Dusun I Desa Kuro Tidur Kecamatan Argamakmur Kabupaten Bengkulu Utara didaptkan masyakat yang ebrpartisiapsi sebanyak 35 orang.

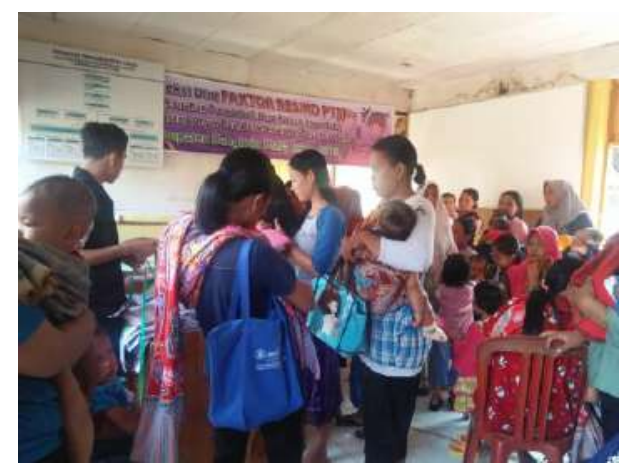

c. Kegiatan Pendidikan Kesehatan

A. Pembukaan

Pelaksanaan kegiatan pendidikan kesehatan dibuka pada pukul 08.00 WIB s/d selesai oleh pihak Puskesmas Perumnas, Dosen Pembimbing Lapangan (DPL) dan mahasiswa Kuliah Kerja Nyata (KKN) Universitas Muhammadiyah Bengkulu. Pelaksanaan Kegiatan 
dilaksanakan di Balai Dusun 4 Desa Kuro Tidur Kecamatan Argamakmur Kabupaten Bengkulu Utara

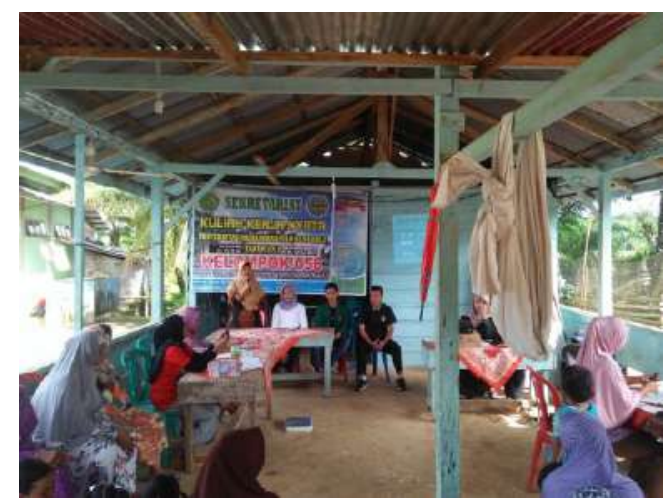

B. Pelaksanaan

Pelaksanaan

Pendidikan

Kesehatan dilaksanakan pada hari Rabu tanggal 05 September 2018. Pada saat sebelum dilaksanakan nya kegiatan dimulai dnegan kata sambutan dari DPL kemudian dilanjutkan dengan arahan dar dari Pihak Puskesmas Argamakmur. Pelaksanaan pendidikan penyuluhan dimulai dengan pemeriksaan kepada bayi dan balita serta pemberiaan imunisasi terlebih dahulu. Kemudian dilanjutkan dengan pemeriksaan kesehatan bagi para ibu hamil. Kegiatan selanjutnya yaitu pendidikan kesehatan melalui penyuluhan kesehatan dengan dimulai dari pemaparan power point tentang Inisiasi Menyusu Dini, ASI Eksklusif dan dilanjutkan dengan Makanan Pendamping ASI. Setelah Pemaparan tersebut dilanjutkan dengan pemutaran video yang telah disiapkan oleh mahasiswa Kuliah Kerja Nyata (KKN) Universitas Muhammadiyah Bengkulu. Partisipasi dari ibu-ibu yang antusias dengan adanya pertanyaan dari ibu-ibu.
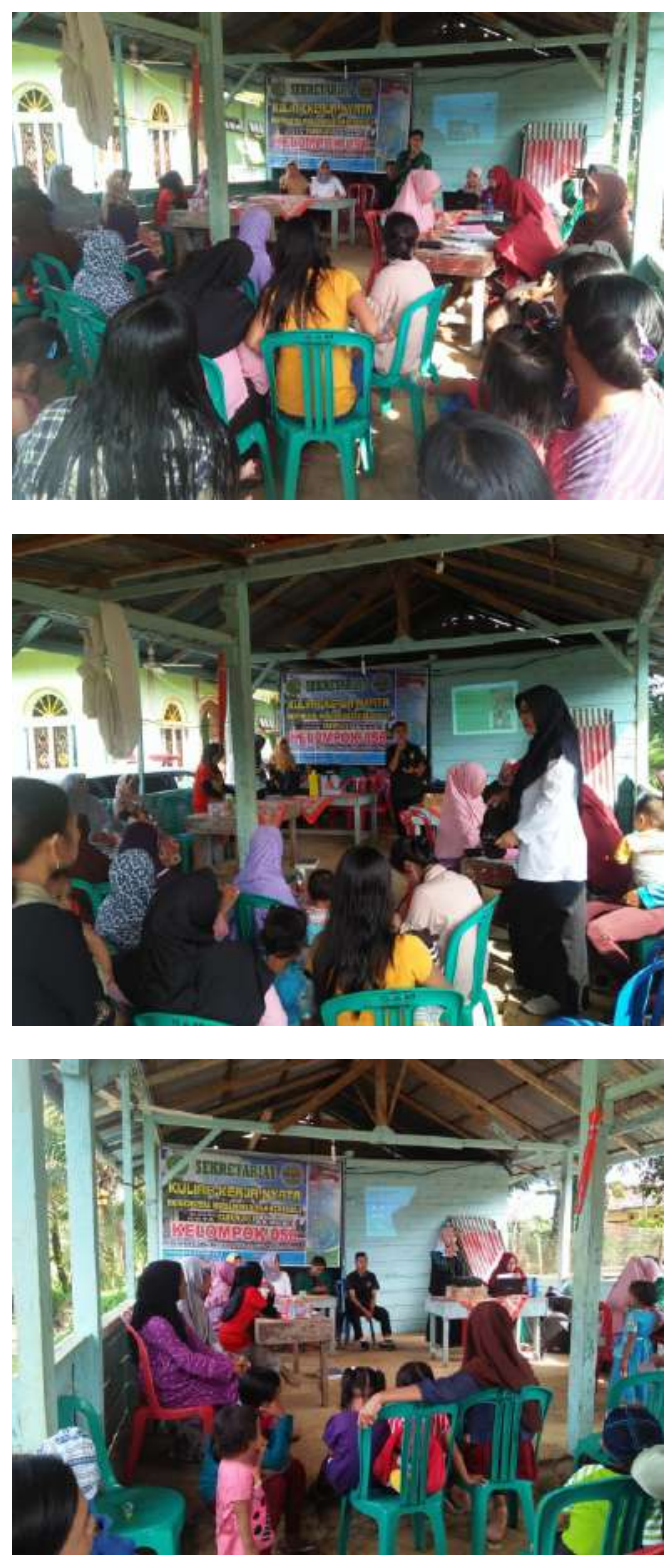

C. Evaluasi

Tercapainya tujuan pendidikan kesehatan melalui penyuluhan kesehatan dengan baik dan para ibu mampu memahami tentang Inisiasi Menyusu Dini, Air Susu Ibu Eksklusif dan Makanan Pendamping ASI dengan baik dan benar.

\section{d. Kegiatan Penutupan Kegiatan Kuliah Kerja Nyata}

A. Pembukaan

Pelaksanaan lokakarya akhir dilaksanakan pada pukul 19.00 WIB s/d selesai oleh mahasiswa KKN di Balai desa Kuro Tidur 
Kecamatan Argamakmur

Kabupaten Bengkulu Utara.

B. Pelaksanaan

Pelaksanaan penutupan kegiatan Kuliah Kerja Nyata (KKN) pada tanggal 8 September 2018 diikuti oleh kepala desa perangkat desa, karang taruna, tokoh masyarakat, masyarakat desa, dan mahasiswa KKN Universitas Muhammadiyah Bengkulu

C. Evaluasi

Tercapainya tujuan penutupan kegaiatn kuliah kerja nyata dengan baik agar masyarakat dapat menerima pengabdian mahasiswa KKN dan menerapkanya dalam kehidupan sehari-hari.

penelitian Maastrup et al (2013) di Denmark Inisiasi Menyusu Dini (IMD) merupakan awal keberhasilan pemberian ASI Eksklusif. Inisiasi Menyusui Dini (IMD) dapat memantapkan ibu untuk memberikan ASI kepada bayi sampai 6 bulan. Memberikan ASI sejak awal kelahiran memberi kesempatan bayi untuk mendapat kolostrum yang kaya akan zat kekebalan tubuh.

Bayi dengan
Ekslusif akan memiliki daya
tahan tubuh yang lebih kuat
dibandingkan dengan bayi yang
diberikan susu formula
(Maryunani, 2012). ASI
memberikan perlindungan
kepada bayi terhadap berbagai
penyakit terutama penyakit
akibat infeksi.

ASI merupakan susu yang tepat untuk bayi karena susu ini khusus diproduksi ibu hanya untuk bayinya. Susu dari ibu memberikan energi yang paling penting untuk bayi. ASI tidak dapat digantikan oleh susu formula yang termahal sekalipun karena zat-zat yang terkadung dalam ASI memiliki suhu yang tepat untuk bayi, mengandung segala zat yang dibutuhkan bayi dan ASI tidak mengandung bakteri yang berbahaya bagi kesehatan bayi (Nirwana, 2014).

Menurut Lestari dkk, 2015 anak yang diberikan MPASI saat usia $\geq 6$ bulan memiliki status gizi yang lebih baik dibandingkan dengan anak yang telah diberi MP-ASI dini. Hal ini karena pada saat bayi berusia 6 bulan keatas system pencernaanya sudah relative sempurna dan siap menerima makanan padat.

Status gizi yang baik pada bayi dapat terjadi jika tubuh dalam keadaan normal (sehat) dan mengkonsumsi makanan dengan kebutuhan akan zat-zat gizinya terjamin. Gizi baik dintandai dengan pertumbuhan berat badan anak sesuai dengan umur. Apabila pertumbuhan berat badan berlebih dari umur anak, maka dikatakan anak mengalami gizi lebih. Bayi juga dapat mengalami gizi kurang apabila tidak memperoleh cukup makanan atau konsumsi energy dan protein yang kurang dari makanan sehari-hari dan pertumbuhan kritis.

Media audio-visual merupakan media yang memliki peranan peningkatan yang signifikan terhadap peningkatan pengetahuan, sikap, dan perilaku ibu tentang ASI Eksklusif, Inisiasi Menyusu Dini, dan MPASI. 
Media ini dapat dijadikan acuan sebagai bahan untuk melakukan pembuatan media promosi kesehatan atau penyuluhan. Selain itu dapat meningkatkan kualitas Sumber Daya Manusia orangtua untuk menghasilkan anak-anak sebagai penerus bangsa yang hebat dalam pembangunan nasional nantinya.

\section{PENUTUP}

\section{a. Kesimpulan}

A. Kegiatan Pelaksanaan survei lapangan pada tanggal 24 Juli 2018 diikuti oleh 20 oang yang terdiri dari kepala desa dan perangkat desa, karang taruna, dosen pendamping lapangan dan mahasiswa kuliah kerja nyata (KKN) Universitas Muhammadiya Bengkulu, Pihak Puskesmas Perumnas Kabupaten Bengkulu Utara

B. Kegiatan Pelaksanaan pemeriksaan kesehatan dilakukan oleh pihak Puskesmas Argamakmur dan mahasiswa Kuliah Kerja nyata (KKN) UNiversitas Muhammadiyah Bengkulu pada tangga 10 Agustus 2018 bertempat di Balai Dusun I Desa Kuro Tidur Kecamatan Argamakmur Kabupaten Bengkulu Utara

C. Kegiatan pelaksanaan pendidikan kesehatan dilaksanakan pada hari Rabu tanggal 05 September 2018. Pelaksanaan pendidikan penyuluhan dimulai dengan pemeriksaan kepada bayi dan balita serta pemberian imunisasi terlebih dahulu. Kemudian dilanjutkan dengan pemeriksaan kesehatan bagi para ibu hamil. Kegiatan selanjutnya yaitu pendidikan kesehatan melalui penyuluhan kesehatan dengan dimulai dari pemaparan power point tentang Inisiasi Menyusu Dini, ASI Eksklusif dan dilanjutkan dengan Makanan Pendamping ASI. Setelah Pemaparan tersebut dilanjutkan dengan pemutaran video yang telah disiapkan oleh mahasiswa Kuliah Kerja Nyata (KKN) Universitas Muhammadiyah Bengkulu. Partisipasi dari ibuibu yang antusias dengan adanay pertanyaan dari ibu-ibu.

D. Kegiatan Pelaksanaan penutupan kegiatan Kuliah Kerja Nyata (KKN) pada tanggal 8 sepetember 2018 diikuti oleh kepala desa perangkat desa, karang taruna, tokoh masyarakat, masyarakat desa, dan mahasiswa KKN Universitas Muhammadiyah Bengkulu

\section{b. Saran}

A. Ibu-ibu di Desa Kuro Tidur Kecamatan Argamakmur Kabupaten Bengkulu Utara diharapkan dapat meningkatkan konsumsi buah-buahan, sayuran kaya vitamin A dan pangan hewani yang kaya akan protein agar dapat mencapai angka kecukupan zat gizi yang sesuai standar. Ibu lebih memperhatikan jenis bahan pangan yang diberikan kepada anak. Salah satunya adalah memberikan jenis pangan sumber karbohidrat dan sumber protein seperti nasi atau bubur serta telur atau sumber protein hewani lainnya yang mudah dan terjangkau oleh keadaan sosial ekonomi keluarga.

B. Sebaiknya bagi Dinas Kesehatan atau petugas kesehatan dapat melakukan penyuluhan menggunakan media audio visual. Media audio visual lebih 
mudah dipahami oleh sasaran ibu-ibu karena lebih atraktif berisikan gerak, gambar dan suara sehingga lebih menarik dan mudah untuk dipahami. lebih sering melakukan kegiatan promosi kesehatan dalam bentuk penyuluhan dan lebih mengajarkan ketrampilan ibuibu di Desa Kuro Tidur agar praktek pemberian ASI dan MP ASI agar dapat berjalan lebih baik sebagaimana mestinya

\section{DAFTAR PUSTAKA}

Ayu, Neng. 2016. Peran Dukungan Orang Tua Faktor yang Paling Berpengaruh terhadap Pemberian ASI Eksklusif. Unnes Jornul of Publich Health 5 (4) Diakses Tanggal 26 April 2018 .

Kementerian Kesehatan RI. 2013. Rencana Kerja Pembinaan Gizi Masyarakat: Direktorat Bina Gizi dan KIA.

Kementerian Kesehatan Republik Indonesia. 2017. Pedoman Penyusunan Profil Hasil Pemantauan Gizi.

Khotimah, Khusnul, IGA, Karnasi, Ayu \& Yuhbaba, Zidni. 2014. Hubungan Antara Konseling ASI Eksklusif pada Ibu Hamil Trimester III dengan Pemberian ASI Eksklusif di Kecamatan Arjasa Kabupaten Jember. Vol.4 No.1. Diakses tanggal 10 April 2018.

Lestari dkk. (2012). Hubungan pemberian Makanan Pendamping Asi (MP-ASI) dengan Status Gizi Anak Usia 1-3 Tahun di Kota Padang Tahun 2012

Martini, Ni Ketut \& Astuti. Ni Putu Widya 2017. Faktor-Faktor Pendorong $\mathrm{Ibu}$ dalam
Pemberian ASI Eksklusif di UPTD Puskesmas II Denpasar Barat. Jurnal Kesehatan Terpadu 1(1) : 12-18 ISSN : 2549-8479 Diakses Tanggal 26 April 2018.

Maastrup, R., Hansen B.M., Kronborg H., Bojesen S.N., Hallum, K., et al. 2014. Factors Associated with Exclusive Breastfeeding of Preterm Infants. Results from a rospective National Cohort Study. PLoS ONE 9(2): e89077.

doi:10.1371/journal.pone. 00890 77.

Maryunani, Anik. 2012. Inisiasi Menyusui Dini, ASI Eksklusif, dan Manajemen Laktasi. Bogor.

Nirwana, Ade Benih. (2014). ASI dan Susu Formula Kandungan dan Manfaat ASI dan Susu Formula. Yogyakarta:Nuha Medika.

Nuraeni, Suryani Soepardan, Bahiyatu \& Ari Soewondo. 2014. Pengaruh Pelaksanaan Konseling dan Pendampingan Suami terhadap Keberhasilan ASI Eksklusif Ibu Menyusui dalam Pemberian Kolustrum. Jurnal Kebidanan Vol.3 No.6 ISSN 2089-7669 Diakses Tanggal 26 April 2018.

Ramlan, Ani Margawati \& Martha I. Kartasurya. 2015. Pengaruh Konseling gizi dan laktasi intensif dan dukungan suami terhadap pemberian ASI Eksklusif sampai umur 1 bulan. Vol.3 No.2, Juni 2015 :101-107 (ISNN :1858-4941)

Riset Kesehatan Dasar. 2013. Kementerian Kesehatan Republik Indonesia 
Vidayanti, Venny \& Melania Wahyuningsih. (2017). Efektifitas konseling laktasi terhadap efikasi diri dan kemampuan menyusui ibu pasca bedah besar. Jurnal Keperawatan Respati Yogyakarta, 4 (2), 154-162

WHO. 2014. Comprehensive implemantion plan on maternal, infant, and young child nutrition. www.who.int.

WHO. 2009. Global health risks: Mortality and burden of disease attributable to selected major risks. Diunduh dari http://www.who.int/healthinfo/ global_burden_disease/Global HealthRisks_report_full.pdf. 